\title{
Odonata assemblages in anthropogenically impacted lotic habitats
}

\author{
Marina Vilenica, ${ }^{1 *}$ Mladen Kerovec, ${ }^{2}$ Ivana Pozojević, ${ }^{2}$ Zlatko Mihaljević ${ }^{2}$ \\ ${ }^{1}$ University of Zagreb, Faculty of Teacher Education, Trg Matice hrvatske 12, Petrinja; ${ }^{2}$ University of Zagreb, Faculty of Science, \\ Department of Biology, Rooseveltov trg 6, Zagreb, Croatia
}

\begin{abstract}
Increasing human pressures have a negative impact on freshwater habitats and their biota worldwide. To protect habitats and the species contained within them, ecological assessments over a gradient of near natural to degraded freshwater habitats are essential. Odonata assemblages were investigated at 46 study sites in Croatia encompassing slightly to heavily modified lowland rivers and streams. Nymphs were sampled between April and September 2016 using a benthos hand net. A total of 19 species was recorded, and Ischnura elegans (Vander Linden, 1820) and Platycnemis pennipes (Pallas, 1771) were most frequently recorded. RDA analysis indicated that water pollution (i.e. levels of chemical oxygen demand and total organic carbon), water temperature and oxygen concentration had the highest influence in the formation of Odonata assemblages at a specific habitat, reflecting their widely recognized bioindicator properties. This study showed that degraded lowland rivers can provide habitat for a relatively low number of species with broad ecological tolerance, while rare and specialist species are generally not able to reproduce there. These results contribute to our knowledge of Odonata occurrence in anthropogenically impacted habitats, and their relationships with such degraded environment.
\end{abstract}

\section{INTRODUCTION}

Odonata (dragonflies and damselflies), as amphibiotic insects, play an important role in transferring materials and energy from aquatic to terrestrial ecosystems (Tsui et al., 2012; Williams et al., 2017; May, 2019). Nymphs inhabit a wide range of freshwater habitats in relation to the biotic and abiotic characteristics, such as predation, food resources, aquatic and riparian vegetation, water temperature, oxygen concentration and $\mathrm{pH}$ (Johansson and Brodin, 2003; Vilenica, 2017; Vilenica et al., 2020). Adult habitat selection primarily relies on the structure of aquatic and riparian vegetation and shading (Steytler and Samways, 1995; Corbet and Brooks, 2008). Both life stages are generalized predators feeding on various small invertebrates, making them important in the regulation of

Corresponding author: marina.vilenica@gmail.com

Key words: Dragonflies; damselflies; species richness; hydromorphological alteration; pollution; environmental factors.

Edited by: Federico Marrone, Department of Biological, Chemical, and Pharmaceutical Sciences and Technologies, University of Palermo, Italy.

Received: 5 May 2020.

Accepted: 7 October 2020.

This work is licensed under a Creative Commons Attribution NonCommercial 4.0 License (CC BY-NC 4.0).

${ }^{\circ}$ Copyright: the Author(s), 2020

Licensee PAGEPress, Italy

J. Limnol., 2021; 80(1):1968

DOI: 10.4081/jlimnol.2020.1968 population abundances of other insects, such as mosquitoes (Corbet and Brooks, 2008; May, 2019). Odonata have been widely used as ecological indicators of environmental quality in aquatic ecosystems (Butler and deMaynadier, 2008; Chovanec and Waringer, 2001) as they inhabit a wide range of freshwater habitats, are strongly affected by anthropogenic changes in freshwater environments, and clearly respond to habitat modification (Samways and Steytler, 1996; Silva et al., 2010; Bried and Samways, 2015). Moreover, Odonata are relatively easily recognized in their adult stages and are popular among professional and amateur entomologists due to their distinctive appearance and behaviour (Boudot and Kalkman, 2015; May, 2019).

The growing human population has resulted in modifications and regulations of various freshwater habitats worldwide (McKinney, 2006), negatively affecting the maintenance of their native biota (Carchini and Rota, 1985; Growns and Growns, 2001; Ferreras-Romero et al., 2009; Golfieri et al., 2018; Kalyoncu and Salur, 2018; Vilenica et al., 2016; 2019; 2020). Freshwater habitats are modified by land use regulating river and streamflow, resulting in changes to hydromorphology, substrate composition, hydrological regime, and water chemistry, which in turn leads to a significant loss of habitat and microhabitat diversity (Strayer and Dudgeon, 2010; Carpenter et al., 2011; Wen et al., 2011). Moreover, due to the extensive urbanization, agriculture and industry, large quantities of pesticides, pharmaceuticals, industrial and domestic waste are discharged daily into freshwaters (Zhang et al., 2004; Arimoro et al., 2008). For effective conservation and management of freshwater habitats, ecological assessments are essential (Hughes et al., 1986; Stoddard et al., 2008), including the collection of detailed data on aquatic communities in both natural and impacted 
habitats, and their relations to environmental factors (Moog, 2002; Hering et al., 2006a, b). With the aim of contributing to such environmental quality assessments, the main goals of this study were to determine Odonata assemblages and their relationships with environmental factors at 46 lowland lotic habitats, along a habitat gradient from slightly to heavily modified.

\section{METHODS}

\section{Study area}

The study was conducted in the Pannonian lowland ecoregion (ER11) in Croatia (Illies, 1978), between April and September 2016. The area is characterized by a temperate humid climate with warm summers (Cfb, Köppen classification) where the average temperature of the warmest month is below $22^{\circ} \mathrm{C}$ (Šegota and Filipčić, 2003). The average annual air temperature is around $12^{\circ} \mathrm{C}$ and the average annual rainfall is between 800 and 1100 mm (Zaninović et al., 2008).

The study was conducted at 46 slow-flowing, small to mid-sized lowland streams and rivers (Supplementary Tabs. 1 and 2, Fig. 1). The sites are characterized by a certain level of anthropogenic disturbance, i.e. channelization and/or modification of the water flow or riverbed, removal of the riparian vegetation, and pollution, as most sites are situated in the vicinity of urban areas, cattle farms, or agricultural fields (detailed description presented in Supplementary Tabs. 1 and 2). The main hydromorphological impacts on these rivers are interventions (past and present) to the river channel, altering the river morphology, though not hydropower related alterations. Channelization of a river or stream not only alters the morphological attributes of the riverbanks and riverbed, but also greatly alters the flow regime (Poff et al., 1997). The magnitude of discharges is generally greater and time to peak discharge is much quicker in channelized streams than in natural streams (King et al., 2009).

\section{Sampling protocol}

Odonata nymphs were collected together with other macroinvertebrates (AQEM protocol- AQEM expert consortium, 2002) between April and September 2016. At each site, 20 subsamples were collected proportionally according to the available microhabitat presence, using a benthos handnet $(25 \times 25 \mathrm{~cm}$; mesh size $=500$ $\mu \mathrm{m})$ and pooled into one composite sample. Substrates were composed mostly of fine sediment (sand, silt, mud), lithal (stones, gravel) and aquatic vegetation (detailed description presented in Supplementary Tab. 1). Samples were stored in $96 \%$ alcohol and analysed in the lab. Nymph identification was after Gerken and Sternberg (1999), Askew (2004), and Brochard et al. (2012).
Macrophytes were assessed using the Reference Index Croatia (RI-HR), which evaluates the difference between a reference community and the actual aquatic vegetation, depending on river type. At most study sites, reference macrophyte communities were absent with no macrophytes or with the presence of degradation indicators such as Cladophora sp., Potamogeton pectinatus, $P$. crispus, P. pusillus, P. berchtoldii, Ceratophyllum demersum, Lemna minor, Lemna sp., Spirodela polyrhiza, Sparganium erectum agg., Typha latifolia, Glyceria fluitans agg., Glyceria maxima. Detailed data on the macrophyte assemblage composition is presented in Kerovec and Ternjej (2017).

\section{Environmental factors}

At each study site, the following environmental parameters were measured at the time of benthic macroinvertebrate sampling: water temperature, dissolved oxygen concentration and saturation (using the oximeter WTW Oxi 330/SET), conductivity (with the conductivity meter WTW LF 330), pH (using the pH-meter WTW ph 330), water width and depth (using a hand meter/measuring tape). The remaining environmental parameters are presented as the mean value of $12 \mathrm{com}-$ posite monthly samples collected over a one-year period (January-December 2016). Water chemistry analyses were carried out according to standard methods (APHA, 1992). Variables describing intensive agricultural land use in the catchment area of each site were calculated with GIS tools, using the CORINE Land Cover classification (CORINE Land Cover Hrvatska, 2013). A relative measure of hydromorphological (HYMO) alternation was given by calculating the River fauna index (RFI) using macroinvertebrate species sensitivity scores. A version of the RFI adapted for Croatian rivers and streams following Urbanič (2014) gives a score of hydromorphological (HYMO) alternation based on the response of macroinvertebrate assemblages. Although this index contains some Odonata indicator taxa as well, a prescreening test showed that the calculations do not differ significantly between RFI scores with and without the Odonata species (RFI groups - explained later in data analysis, based on this index are completely equal). The scores are then normalized with regard to reference states in the form of the WFD (Water Framework Directive) recommended EQRs (ecological quality ratios), ranging from 0 (the worst $\mathrm{HYMO}$ conditions) to 1 (reflecting reference states). The hydromorphological evaluation of rivers was performed based on the European Standards EN 14614 and EN 15843. Type specific River fauna index (RFI) was used as a relative measure of HYMO alternation since hydromorphological evaluations were not available for all of the investigated rivers. 


\section{Data analysis}

In order to show similarities in the composition of Odonata assemblages among study sites with different RFI values, we applied a Cluster analysis using the zeroadjusted Bray-Curtis similarity index (the zero-adjusted version was used in order to consider the sites with no Odonata). SIMPER analysis was performed to determine how Odonata assemblages differ among sites with varying degrees of RFI values in terms of their species composition and abundance contribution. Odonata assemblages from sites classified as high and good by the RFI EQR $(\mathrm{EQR}>0.6)$ represented Group 1, from moderate sites $(0.4>\mathrm{EQR}<0.6)$ represented Group 2 and from sites classified as poor and bad $(\mathrm{EQR}<0.4)$ represented Group 3 in the Cluster analysis and SIMPER of the (zero-adjusted Bray-Curtis) similarity between Odonata assemblages.

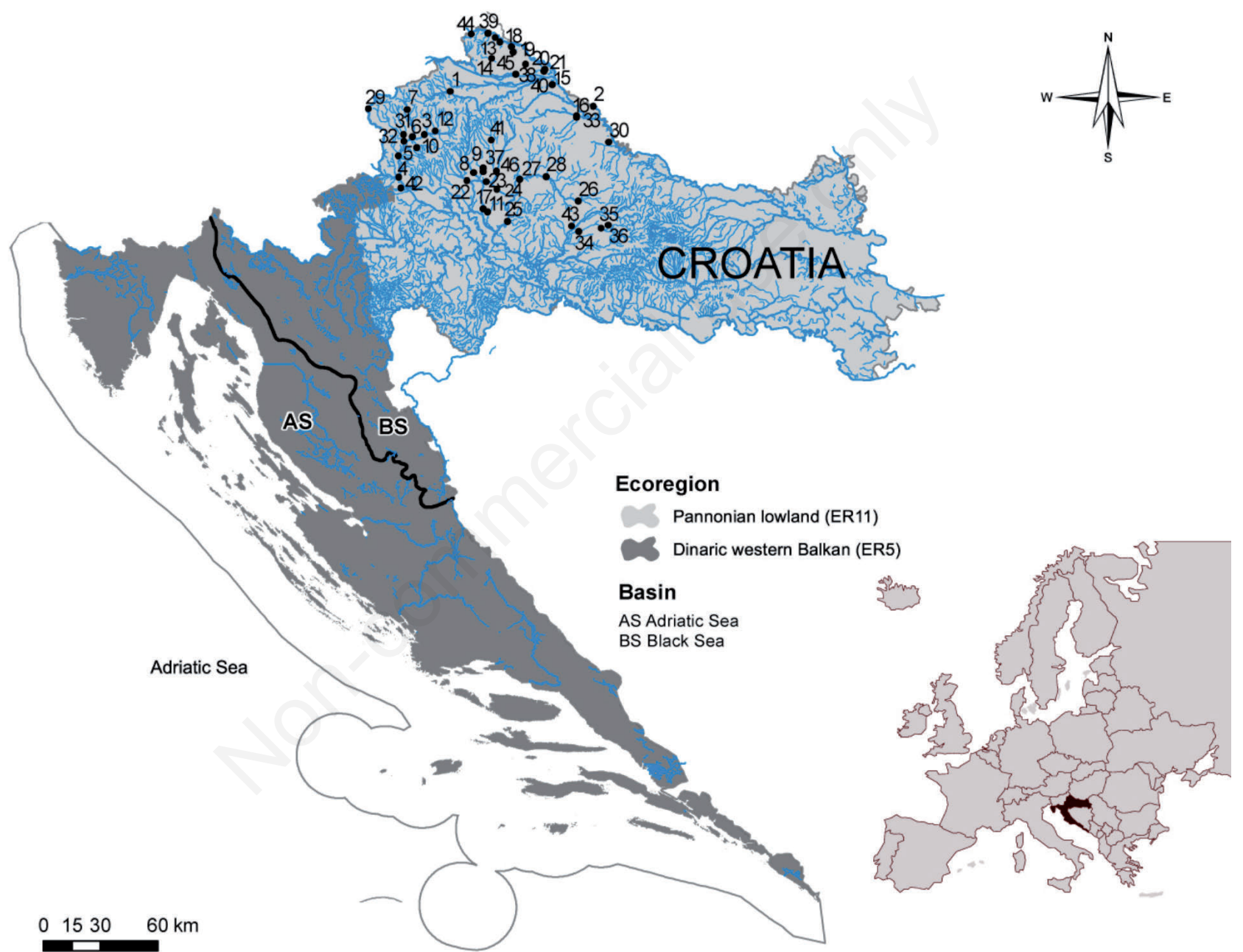

Fig. 1. Map of the 46 anthropogenically impacted study sites located in the Pannonian lowland ecoregion in Croatia.

Study sites: 1 - Bednja, Stažnjevec village; 2 - Ždalica, Ždala village; 3 - Krapina, Bedekovčina village; 4 - Krapina, Zaprešić town; 5 - Krapina, Kupljenovo village; 6 - Krapinica, Zabok town; 7 - Krapinica, Krapina town; 8 - Rajna, between Vrbovec town and Lonjica village; 9 - Zlenin, Vrbovec village; 10 - Vukšinac, Stubice village; 11 - Deanovac lateral canal, near Ivanić Grad town; 12 - Reka, Lovrečan village, 13 - Brodec, Peklenica village; 14 - Lateral canal Mihovljan, Čakovec town; 15 - Poloj, between Legrad and Đelekovec villages; 16 - Zdelja, Molve village; 17 - Lonja, near Ivanić Grad town; 18 - Jalšovnica, Ferketinec village; 19 - Bošćak, Domašinec village; 20 - Bistrec, Rakovnica I; 21 - Bistrec, Rakovnica II; 22 - Zelina, Božjakovina village; 23 - Connecting canal Zelina-Lonja-Glogovnica-Česma, Poljanski lug village; 24 - Glogovnica, before mouth to Česma; 25 Česma, Obedišće village; 26 - Česma, Pavlovac village; 27 - Česma, Sišćani village; 28 - Česma, Narta village; 29 - Sutla, Luke Poljanske village; 30 - Rogostrug, Podravske Sesvete village; 31 - Kosteljina, Jalšje village; 32 - Horvatska, Veliko Trgovišće village; 33 - Bistra Koprivnička, Molve village; 34 - Toplica, Sokolovac village; 35 - Toplica, downstream from Daruvar town; 36 - Toplica, upstream from Daruvar town; 37 - Luka, Vrbovec town; 38 - Sewage collector, Prelog town; 39 - Gornji potok, between Selnica and Praporčan villages; 40 - Kotoribski kanal, Kotoriba village; 41 - Črnec, Gornji Dubovec vilage; 42 - Gostiraj, Ježdovec village; 43 - Tomašica, Tomašica village; 44 - Jalšovec, between Bukovje and Štrigova villages; 45 - Murščak, between Domašinec and Stara Straža villages; 46 - Glogovnica, Koritna village. 
Redundancy analysis (RDA) was used to ordinate Odonata occurrence with respect to environmental variables. The analysis was performed using data for 25 taxa (rare taxa were downweighed) and 11 selected environmental variables. The Monte Carlo permutation test with 499 permutations was used to test the statistical significance of the relationship between all taxa and all variables.

Odonata taxa abundances were correlated against agricultural land cover data, using the Spearman coefficient to determine if, and to what extent, the type of land cover in the catchment area influences specific taxa occurrence.

The zero-adjusted Bray-Curtis similarity index, Cluster and SIMPER analysis were conducted in Primer 6 (Clarke and Gorley, 2006). The RDA analysis was performed using CANOCO 5.00 (ter Braak and Šmilauer, 2012). The Spearman coefficient was calculated using Statistica 13.0 (TIBCO Software Inc., 2017). Species data were log-transformed prior to analyses to give a more balanced ordination of abundance data and so the data could better reveal the structure of our community giving biological relevance not only to the few dominant species (Májeková et al., 2016). All figures were processed with Adobe Illustrator CS6.

\section{RESULTS}

\section{Odonata assemblages}

A total of 19 species (25 taxa, of which 6 belonged to juvenile and/or damaged individuals) was recorded, with Ischnura elegans and Platycnemis pennipes most frequently recorded (at 13 study sites) (Supplementary Tab. 3). Study site 28 (Česma River at Narta) had the highest species richness with five recorded species. Twelve sites had no Odonata records (Supplementary Tab. 3). Only one endangered/protected species was recorded: Onychogomphus cecilia (VU, Red List of Croatian Odonata Fauna, Belančić et al., 2008), found at the Sutla River (site 29). Cluster analysis (Fig. 2) did not show any specific grouping of study sites based on RFI scoring.

\section{Environmental variables}

Among the study sites, water temperature ranged between 9 and $25^{\circ} \mathrm{C}$, oxygen concentration between 1.53 and $10.70 \mathrm{mg} / \mathrm{L}$, conductivity between 207 and 982 $\mu \mathrm{S} / \mathrm{cm}$, $\mathrm{pH}$ between 5.68 and 9.20 , ammonium concentration between 0.014 and $5.007 \mathrm{mgN} / \mathrm{L}$, nitrates between 0.100 and $6.541 \mathrm{mgN} / \mathrm{L}$, total nitrogen between 0.466 and $14.023 \mathrm{mgN} / \mathrm{L}$, orthophosphates between 0.010 and 6.545 $\mathrm{mgP} / \mathrm{L}$, total organic carbon between 1.000 and 27.671 $\mathrm{mgC} / \mathrm{L}$, biological oxygen demand between 0.729 and $22.856 \mathrm{mgO}_{2} / \mathrm{L}$, and chemical oxygen demand between 0.936 and $18.933 \mathrm{mgO}_{2} / \mathrm{L}$ (Supplementary Tab. 1).

\section{Environmental variables and Odonata}

The results of the ordination of species and environmental data of the RDA analysis are presented on the F1 $\times$ F2 ordination plot. The eigenvalues for the first two RDA axes were 0.15 and 0.05 and together explained $61.2 \%$ of the species-environment relations. The Monte Carlo permutation test showed that the species-environment ordination was significant (first axis: $\mathrm{F}$-ratio $=5.82$, $\mathrm{p}=0.03$; overall: trace $=0.31, \mathrm{~F}=1.44, \mathrm{p}=0.04$ ) indicating that Odonata assemblages were significantly related to the tested set of environmental variables. Axis 1 was related to chemical oxygen demand $(\mathrm{R}=0.41)$ and total organic carbon $(\mathrm{R}=0.27)$ and axis 2 to water temperature $(\mathrm{R}=0.35)$

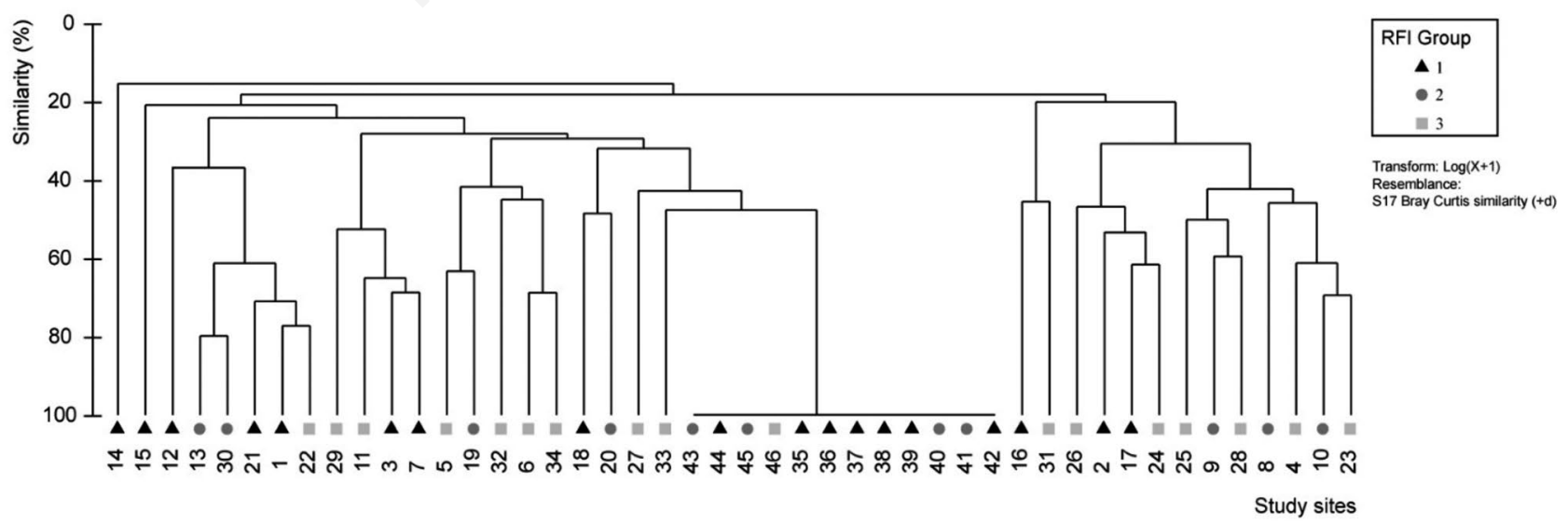

Fig. 2. Cluster analysis of Odonata assemblages based on the zero-adjusted Bray-Curtis similarity coefficient (group average linking) and their log-transformed abundances at 46 anthropogenically impacted habitats in Croatia ("zero dummy" added for sites with no Odonata records). Abbreviations of the study sites are presented in Fig. 1. RFI - Groups are as in Supplementary Tab. 1. 
and dissolved oxygen concentration $(\mathrm{R}=0.35)$, indicating that these were the most important parameters in explaining patterns of Odonata assemblages (Fig. 3).

The SIMPER group similarity analysis (Tab. 1) showed that all groups of sites (Group 1 - good and high EQR, Group 2 - moderate EQR, and Group 3 - poor and bad EQR based on RFI) were associated with the ubiquitous taxa Platycnemis pennipes and Ischnura elegans. Onychogomphus forcipatus individuals were frequently found in both the poor and bad Group 3 and the good and high Group 1 sites. Gomphus vulgatissimus and Somatochlora meridionalis were predominantly associated with sites having higher RFI values (Group 1), whereas Calopteryx splendens was usually associated with more degraded sites (sites with lower RFI EQR values, Group 3).

Abundance of Calopteryx splendens $(\mathrm{r}=0.323$; $\mathrm{p}=0.029)$ and Aeshna cyanea $(\mathrm{r}=0.301 ; \mathrm{p}=0.042)$ significantly increased with increasing ratios of intensive agriculture in the catchment area, whereas other Odonata species did not show significant correlations to intensive agriculture in the catchment.

\section{DISCUSSION}

The results indicate a moderately high species richness of anthropogenically impacted lotic habitats, with the presence of $28 \%$ of the total Croatian Odonata fauna (Belančić et al., 2008; Boudot and Kalkman, 2015). Never- theless, with an average of two or three species per site, the local species richness is far from high. These results

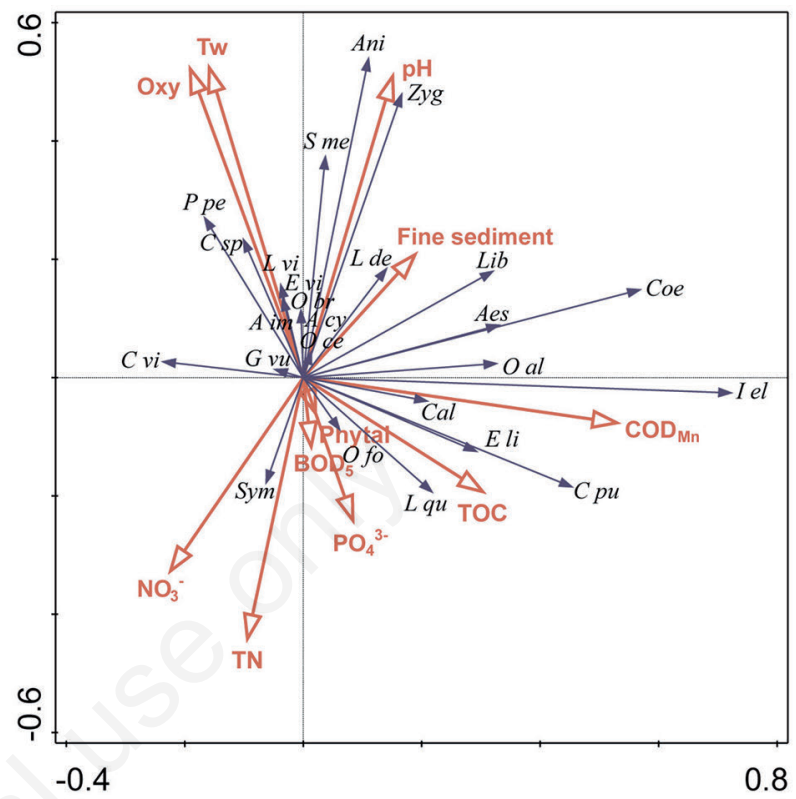

Fig. 3. F1 $\times$ F2 plane of RDA analysis for 25 Odonata taxa and 11 environmental variables. Legend: Values and abbreviations of environmental parameters (red arrows) are presented in Supplementary Tab. 1 and taxa codes (blue arrows) are presented in Supplementary Tab. 3.

Tab. 1. Results of the SIMPER analysis based on Odonata assemblages from sites of different River fauna index (RFI) values. RFI Groups are as in Supplementary Tab. 1.

\begin{tabular}{|c|c|c|}
\hline Species & $\begin{array}{l}\text { Average abundance per site } \\
\qquad \text { (ind } / \mathrm{m}^{2} \text { ) }\end{array}$ & $\begin{array}{l}\text { Similarity contribution within group } \\
\qquad(\%)\end{array}$ \\
\hline \multicolumn{3}{|c|}{$\begin{array}{l}\text { Group } 1 \text { - good and high EQR based on RFI }(\mathrm{EQR}>0.6) \\
\text { Average similarity: } 8.98\end{array}$} \\
\hline $\begin{array}{l}\text { Gomphus vulgatissimus } \\
\text { Onychogomphus forcipatus } \\
\text { Platycnemis pennipes } \\
\text { Ischnura elegans } \\
\text { Somatochlora meridionalis } \\
\text { Calopteryx virgo }\end{array}$ & $\begin{array}{l}0.62 \\
0.35 \\
0.38 \\
0.28 \\
0.34 \\
0.36\end{array}$ & $\begin{array}{c}47.23 \\
12.78 \\
12.62 \\
9.27 \\
6.95 \\
6.77\end{array}$ \\
\hline \multicolumn{3}{|c|}{$\begin{array}{l}\text { Group } 2 \text { - moderate EQR based on RFI }(0.4>\mathrm{EQR}<0.6) \\
\text { Average similarity: } 6.71\end{array}$} \\
\hline $\begin{array}{l}\text { Calopteryx virgo } \\
\text { Platycnemis pennipes } \\
\text { Ischnura elegans } \\
\text { Coenagrionidae juv. }\end{array}$ & $\begin{array}{l}0.55 \\
0.77 \\
1.27 \\
1.20\end{array}$ & $\begin{array}{l}31.43 \\
22.80 \\
21.42 \\
19.90\end{array}$ \\
\hline \multicolumn{3}{|c|}{$\begin{array}{l}\text { Group } 3 \text { - poor and bad EQR based on RFI }(\mathrm{EQR}<0.4) \\
\text { Average similarity: } 15.24\end{array}$} \\
\hline $\begin{array}{l}\text { Ischnura elegans } \\
\text { Platycnemis pennipes } \\
\text { Calopteryx splendens } \\
\text { Coenagrionidae juv. } \\
\text { Onychogomphus forcipatus }\end{array}$ & $\begin{array}{l}1.36 \\
1.48 \\
0.88 \\
0.73 \\
0.46\end{array}$ & $\begin{array}{c}33.02 \\
31.03 \\
13.20 \\
7.61 \\
6.24\end{array}$ \\
\hline
\end{tabular}


corroborate those presented by Vilenica et al. (2020) referring to lentic waterbodies. However, it is important to emphasize that the sampling protocol (AQEM methodology) used enables the assessment of ecological quality in European streams based on benthic macroinvertebrates, following the same unified evaluation scheme (AQEM consortium, 2002). As such, it was not designed as a model for studying Odonata, which in our case, probably resulted in incomplete species list at a particular site. Furthermore, different Odonata life stages are faced with different ecological limitations and mobility (aquatic vs. aerial), and the different sampling methods employed likely lead to the incomparability of results (Giugliano et al., 2012). In order to more accurately understand species richness and its relationship with a particular habitat, all phases of the Odonata life cycle must be considered, i.e. nymphs, exuviae and adults (Horning and Pollard, 1978; Samways et al., 2009; Raebel et al., 2010; Golfieri et al., 2016). Some studies have shown that nymphal diversity in polluted streams may be considerably lower than that of adults (as seen in May 2019). Site sampling should also be conducted on multiple occasions to ensure the collection of both spring and summer species (Askew, 2004; Corbet and Brooks, 2008; Dijkstra and Lewington, 2006). Therefore, the absence of Odonata from a rather high number of sites and their general low abundance could be related to the poor ecological quality of studied sites, but could also have been partly influenced by the sampling methodology here implemented, which should be inspected with more Odonata-focused future studies. Previous studies have shown that near-natural lowland rivers are characterized by higher Odonata diversity due to the heterogeneous habitat structure (Raab, 1998; Buczyński, 2012, Golfieri et al., 2016.), where e.g. various Cordulegaster species can occur in the rhithron, while species such as Coenagrion ornatum (Selys, 1850), Orthetrum brunneum (Fonscolombe, 1837) and Gomphus flavipes (Charpentier, 1825) could be found in the potamon (Dijkstra and Lewington, 2006; Chovanec et al., 2015).

The majority of the species reported here are characteristic both for lotic and lentic habitats (such as Erythromma lindenii, Onychogomphus forcipatus), though predominantly lotic (such as Calopteryx virgo) and lentic species (such as Coenagrion puella, Aeshna cyanea) were also recorded (Janecek et al., 1995; Schmedtje and Colling, 1996; in AQEM expert consortium, 2002). The Cluster analysis did not reveal similarities between the study sites based on the degree of hydromorphological alteration, likely since the majority of species are generalists with a broad distribution and ecological tolerance for habitat conditions (e.g., Coenagrion puella, Ischnura elegans, Libellula depressa), corroborating previous studies (Samways and Steytler, 1995; Vilenica et al., 2020). Therefore, it is not surpris- ing that the eurytopic Ischnura elegans together with Platycnemis pennipes, a species that inhabits a wide range of lotic habitats (Dijkstra and Lewington, 2006), were also the most widespread in this study. Many authors have stated that the dominance of Ischnura elegans might indicate heavily contaminated running water systems (Rehfeldt, 1983; Solimini et al., 1997). Moreover, Heidemann and Seidenbusch (1993) extended this observation to a range of abiotic factors (contamination, salinity, oxygen saturation), and concluded that this species can survive under conditions which no other (European) dragonfly species can tolerate. Several riverine species that can also be present in lentic habitats (Onychogomphus focipatus, Gomphus vulgatissimus, Somatochlora meridionalis, Calopteryx splendens) showed various incidences at habitats of different degree of hydromorphological alteration, likely related to their higher preference for oxygenated habitats than to habitats of a specific morphology (Janecek et al., 1995; Schmedtje and Colling, 1996; Kalkman et al., 2018).

Flow regulations result in a significant decline in diversity of macrozoobenthic communities, including Odonata, due to the loss of habitat and microhabitat heterogeneity (Usseglio-Polatera and Beisel, 2002; Vilenica et al., 2016; Chovanec, 2018). Our results indicate that degraded habitats are not suitable for rare and endangered species. Nevertheless, at the national level, the record of the vulnerable (VU) species Ophiogomphus cecilia at the Sutla River (site 29) is highly important. This species has a limited distribution in continental Croatia, and its populations are threatened by modifications and regulations of lowland rivers (Belančić et al., 2008). Although the site is characterized by a high level of hydromorphological alteration, the water chemistry is not poor thus enabling the species occurrence at this site. Ophiogomphus cecilia is a typical burrower preferring sandy substrates, while adults require the presence of surrounding vegetation for resting (Askew, 2004; Hacet and Aktaç, 2008), and these conditions were present at this site. However, given the low abundance, its presence could also be considered as accidental, and should be inspected in greater detail with future species-targeted studies along the whole river course.

Previous studies have shown that the presence of aquatic and riparian vegetation, water velocity and temperature, and substrate grain size are the most important parameters influencing Odonates in lotic habitats (Hardersen, 2008; Silva et al., 2010, Golfieri et al. 2016). In this study, Odonata assemblages were highly influenced by descriptors of the polluted aquatic environment, i.e. chemical oxygen demand and total organic carbon in water, likely originating from domestic sewage, surrounding agricultural fields and cattle farms (Shi et al., 2010). Moreover, two species with rather differing eco- 
logical demands, Aeshna cyanea and Calopteryx splendens, seemed to be rather successful in a polluted environment, as their abundances increased with increasing ratios of intensive agriculture area in the catchment area. Calopteryx splendens is an euryecious species, favouring unshaded streams and rivers and achieving its maximum in natural, relatively slow lowing lowland rivers open to the sun. In contrast, Aeshna cyanea can mostly be found in small and at least partly shaded standing waters (Askew, 2004; Dijkstra and Lewington, 2006). What they have in common is their ability to inhabit alpha- and betamesosaphrobic waters (Janecek et al., 1995; Mihaljević, 2011). Furthermore, heavily polluted sites were also characterized by higher water temperature and low oxygen concentration, two additional variables that have proven to be important determinants for Odonata occurrence (Sato and Riddiford, 2007; McPeek 2008). These sites were also overgrown by dense vegetation. Excessive growth of aquatic macrophytes and algae is supported by the high level inflow of nutrients in water, consequently resulting in low oxygen concentrations in the water-body (Boeykens et al., 2017), which in turn limits the Odonata presence at such habitats (Rose and Crumpton, 1996). Therefore, less polluted sites with higher oxygen levels and lower water temperatures harbour more Odonata species (Osborn, 2005).

\section{CONCLUSIONS}

This study confirms the bioindicator properties of Odonata and shows their sensitivity to water pollution. Our findings confirmed that human pressures on the lotic freshwater system result in impoverished Odonata assemblages that consist mainly of widespread, common species, while the rare and protected species are generally not able to reproduce there. These results contribute to our knowledge of Odonata occurrence in anthropogenically impacted habitats, and their relationships with such degraded environment.

\section{ACKNOWLEDGEMENTS}

We would like to thank our colleagues from University of Zagreb (Faculty of Science, Department of Biology, Division of Zoology) for their indispensable assistance during field surveys and for assistance in sorting the collected material. Miran Katar is thanked for assisting with the artwork. We thank Maja Kerovec for assisting with GIS analysis and Croatian Waters for providing hydromorphological, land use and water physicochemical data. Finally, we are thankful to the anonymous reviewers for their useful suggestions that markedly improved our manuscript.

\section{REFERENCES}

APHA, American Public Health Association, 1992. Standard Methods for the Examination of Water and Wastewater, 18th ed. Washington, DC.

AQEM expert consortium, 2002. Ecological classifications by AQEM expert consortium. www.aqem.de

AQEM consortium, 2002. Manual for the application of the AQEM method. A comprehensive method to assess European streams using benthic macroinvertebrates, developed for the purpose of the Water Framework Directive. Version 1.0, February 2002.

Arimoro FO, Chukwuji MAI, Ogheneghalome O, 2008. Effects of industrial waste water on the physical and chemical characteristics of a tropical coastal river. Res. J. Environ. Sci. 2(3):209-220.

Askew RR, 2004. The dragonflies of Europe. Second Edition, Harley Books, Essex: 308 pp.

Belančić A, Bogdanović T, Franković M, Ljuština M, Mihoković N, Vitas B, 2008. [Red book of Croatian Odonata].[Book in Croatian]. Ministry of Culture, State Department for Nature Protection, Zagreb: $132 \mathrm{pp}$.

Boeykens SP, Piol MN, Legal LS, Saralegui AB, Vázquez C, 2017. Eutrophication decrease: phosphate adsorption processes in presence of nitrates. J. Environ. Manag. 203:888-895.

Boudot J-P, Kalkman VJ, 2015. Atlas of the European dragonflies and damselflies. KNNV publishers, Zeist: $381 \mathrm{pp.}$

Bried JT, Samways MJ, 2015. A review of odonatology in freshwater applied ecology and conservation science. Freshw. Sci. 34:1023-1031.

Brochard C, Groendijk D, van der Ploeg E, Termaat T, 2012. [Fotogids Larvenhuidjes van Libellen].[Book in Dutch]. KNNV publishers, Zeist: 320 pp.

Buczyński P, 2012. Dragonflies (Odonata) of the left-bank Bug River valley between Włodawa and Kodeń (middle-eastern Poland). Acta Biol. 19:47-69.

Butler RG, deMaynadier PG, 2007. The significance of littoral and shoreline habitat integrity to the conservation of lacustrine damselflies (Odonata). J. Insect Conserv. 12:23-36.

Carchini G, Rota E, 1985. Chemico-physical data on the habitats of rheophile Odonata from central Italy. Odonatologica 14:239-245.

Carpenter SR, Stanley EH, Vander Zanden MJ, 2011. State of the world's freshwater ecosystems: physical, chemical, and biological changes. Annu. Rev. Env. Resour. 36:75-99.

Chovanec A, 2018. Comparing and evaluating the dragonfly fauna (Odonata) of regulated and rehabilitated stretches of the fourth order metarhithron Gurtenbach (Upper Austria). Int. J. Odonatol. 21:15-32.

Chovanec A, Waringer J, 2001. Ecological integrity of riverfloodplain systems assessment by dragonfly surveys (Insecta: Odonata). Regul. Rivers: Res. Manage. 17:493-507.

Chovanec A, Schindler M, Waringer J, Wimmer R, 2015. The dragonfly association index (Insecta: Odonata) - a tool for the type-specific assessment of lowland river. River Res. Appl. 3:627-638.

Clarke KR, Gorley RN, 2006. Primer V6: User Manual / Tutorial. Primer-E, Plymouth.

CORINE Land Cover Croatia, 2013. Croatian Environment and 
Nature Agency. Available from: http://www.haop.hr/hr/ corine-land-cover-hrvatska-clc-hrvatska/corine-land-coverhrvatska-clc-hrvatska

Corbet P, Brooks S, 2008. Dragonflies. Collins New Naturalist Library No 106. HarperCollins: London: $480 \mathrm{pp}$.

Dijkstra K-DB, Lewington R, 2006. Field Guide to the Dragonflies of Britain and Europe. British Wildlife Publishing, Gillingham: 320 pp.

Ferreras-Romero M, Márquez-Rodríguez J, Ruiz-García A, 2009. Implications of anthropogenic disturbance factors on the Odonata assemblage in a Mediterranean fluvial system. Int. J. Odonatol. 12:413-428.

Gerken B, Sternberg K, 1999. [Die Exuvien Europaïscher Libellen - The exuviae of European Dragonflies (Insecta, Odonata)].[Book in German]. Arnika \& Eisvogel, Jena: 354 pp.

Giugliano L, Hardersen S, Santini G, 2012. Odonata communities in retrodunal ponds: a comparison of sampling methods. Int. J. Odonatol. 15:13-23.

Golfieri B, Hardersen S, Maiolini B, Surian N, 2016. Odonates as indicators of the ecological integrity of the river corridor: development and application of the Odonate River Index (ORI) in northern Italy. Ecol. Indic. 61:234-247.

Golfieri B, Surian N, Hardersen S, 2018. Towards a more comprehensive assessment of river corridor conditions: A comparison between the Morphological Quality Index and three biotic indices. Ecol. Indic. 84:525-534.

Growns IO, Growns JE, 2001. Ecological effects of flow regulation on macroinvertebrate and periphytic diatom assemblages in the Hawkesbury-Nepean River, Australia. Regul. Rivers: Res. Manage. 17:275-293.

Hacet N, Aktaç N, 2008. Two new records of Odonata (Gomphidae) for Turkey, Gomphus flavipes (Charpentier, 1825) and Ophiogomphus cecilia (Geoffroy in Fourcroy, 1785), with distributional notes on G. flavipes and G. ubadschii Schmidt, 1953. Entomol. News 119:81-89.

Hardersen S, 2008. Dragonfly (Odonata) communities at three lotic sites with different hydrological characteristics. Ital. J. Zool 75:271-283.

Heidemann H, Seidenbusch R, 1993. [Die Libellenlarven Deutschlands und Frankreichs].[Book in German]. Verlag Erna Bauer, Keltern: 391 pp.

Hering D, Johnson RK, Kramm S, Schmutz S, Szoszkiewicz K, Verdonschot PFM, 2006a. Assessment of European rivers with diatoms, macrophytes, invertebrates and fish: a comparative metric-based analysis of organism response to stress. Freshwater Biol. 51:1757-1785.

Hering D, Feld CK, Moog O, Ofenböck T, 2006b. Cook book for the development of a multimetric index for biological condition of aquatic ecosystems: experiences from the European AQEM and STAR projects and related initiatives. Hydrobiologia 566:311-324.

Horning CE, Pollard JE, 1978. Macroinvertebrate sampling techniques for streams in semi-arid regions: Comparison of the Surber method and unit-effort traveling Kick method. Report number EPA 600-4-78-040, US EPA, Washington: 37 pp.

Hughes RM, Larsen DP, Omemik JM, 1986. Regional reference sites: a method for assessing stream pollution. Environ. Manage. 10:629-635.

Illies J, 1978. Limnofauna Europaea. Stuttgart, Gustav Fischer Verlag: $532 \mathrm{pp}$.
Janecek BFU, Moog O, Waringer J, 1995. Odonata. In: O. Moog (ed.), Fauna Aquatica Austriaca, Lieferungen 1995, 2002. Vienna, Wasserwirtschaftskataster, Bundesministerium für Land- und Forstwirtschaft, Umwelt und Wasserwirtschaft.

Johansson F, Brodin T 2003. Effects of fish predators and abiotic factors on dragonfly community structure. J. Freshwat. Ecol. 18:415-423.

Kalkman V, Boudot J, Bernard R, De Knijf G, Suhling F, Termaat T, 2018. Diversity and conservation of European dragonflies and damselflies (Odonata). Hydrobiologia 811: 269-282.

Kalyoncu H, Salur A, 2018. Odonata fauna of Alara and Karpuz streams and their relations with physico-chemical variables. Fresenius Environ. Bull. 27:187-195.

King KW, Smiley Jr PC, Fausey NR, 2009. Hydrology of channelized and natural headwater streams. Hydrol. Sci. J. 54:929-948.

Kerovec M, Ternjej I, 2017. [Study of systematic testing of biological quality elements in surface inland waters in 2016]. [in Croatian] Faculty of Science, University of Zagreb: $50 \mathrm{pp}$.

Májeková M, Paal T, Plowman NS, Bryndová M, Kasari L, Norberg A, Weiss M, Bishop TR, Luke SH, Sam K, Le Bagousse-Pinguet Y, Lepš J, Götzenberger L, de Bello F. 2016. Evaluating functional diversity: missing trait data and the importance of species abundance structure and data transformation. PLoS One11:e0149270.

May ML, 2019. Odonata: who they are and what they have done for us lately: classification and ecosystem services of dragonflies. Insects 10:1-17.

McKinney ML, 2006. Urbanization as a major cause of biotic homogenization. Biol. Conserv. 127:247-260.

McPeek MA, 2008. Ecological factors limiting the distributions and abundances of Odonata, p. 51-62. In: A. Córdoba-Aguilar (ed.), Dragonflies: Model organisms for ecological and evolutionary research. Oxford University Press, Oxford.

Mihaljević Z, 2011. [Revision of Croatian indicator system]. In: Z. Mihaljević (ed.), [Testing of biological methods for ecological status assessment (Water Framework Directive 2000/60/EC) in representative river basins of the Pannonian and Dinaric ecoregions]. [in Croatian]. Faculty of Science, University of Zagreb.

Moog O, 2002. Fauna Aquatica Austriaca. Vienna, Wassserwirtschaftskataster, Bundesministerium für Land- und Forstwirtschaft, Umwelt und Wasserwirtschaft.

Osborn R, 2005. Odonata as indicators of habitat quality at lakes in Louisiana, United States. Odonatologica 34:259-270.

Poff NL, Allan JD, Bain MB, Karr JR, Prestegaard KL, Richter BD, Sparks RE, Stromberg JC, 1997. The natural flow regime. BioScience 47:769-784

Raab R, 1998. [Die Libellen- und Vogelfauna im Waldviertel, p. 9-46]. In: Österreich WWF (ed.), [Natura 2000 im Waldviertel. Faunistische Erhebungen und Managementpläne im Rahmen eines LIFE-Projektes].[Book in German]. Vienna, Österreich WWF.

Raebel EM, Merckx T, Riordan P, Macdonald DW, Thompson DJ, 2010). The dragonfly delusion: why it is essential to sample exuviae to avoid biased surveys. J. Insect Conserv. 14: 523-534. 
Rehfeldt G, 1983. [Die Libellen (Odonata) des nördlichen Harzrandes].[Article in German]. Braunschw. Naturkdl. Schr. 1:603-654.

Rose C, Crumpton WG, 1996. Effects of emergent macrophytes on dissolved oxygen dynamics in a prairie pothole wetland. Wetlands 16:495-502.

Samways MJ, McGeoch MA, New TR, 2009. Insect conservation: handbook of approaches and methods. Oxford University Press, Oxford: 432 pp.

Samways MJ, Steytler NS, 1996. Dragonfly (Odonata) distribution patterns in urban and forest landscapes, and recommendations for riparian management. Biol. Conserv. 78:279-288.

Sato M, Riddiford N, 2007. A preliminary study of the Odonata of S'Albufera Natural Park, Mallorca Natural Park, Mallorca: status, conservation priorities and bio-indicator potential. J. Insect Conserv. 12:539-548.

Schmedtje U, Colling M, 1996. [Ökologische Typisierung der aquatischen Makrofauna].[Book in German]. Informationsberichte des Bayerischen Landesamtes für Wasserwirtschaft: 543 pp.

Shi Y, Xu L, Gong D, Lu J, 2010. Effects of sterilization treatments on the analysis of TOC in water samples. J. Environ. Sc. 22:789-795

Silva DP, De Marco PJr, Resende DC, 2010. Adult odonate abundance and community assemblage measures as indicators of stream ecological integrity: A case study. Ecol. Indic. 10:744-752.

Solimini AG, Tarallo GA, Carchini G, 1997. Life history and species composition of the damselfly assemblage along the urban tract of a river in central Italy. Hydrobiologia 356:21-32.

Steytler NS, Samways MJ, 1995. Biotope selection by adult male dragonflies (Odonata) at an artificial lake created for insect conservation in South Africa. Biol. Conserv. 72:381- 86.

Stoddard JL, Herlihy AT, Peck DV, Hughes RM, Whittier TR, Tarquinio E, 2008. A process for creating multimetric indices for large-scale aquatic surveys. J. N. Am. Benthol. Soc. 27:878-891.

Strayer DL, Dudgeon D. 2010. Freshwater biodiversity conservation: recent progress and future challenges. J. N. Am. Benthol. Soc. 29:344-58.

Šegota T, Filipčić A, 2003. [Köppen's division of climate and Croatian terminology].[Article in Croatian]. Geoadria 8:17.23.

ter Braak CJF, Smilauer P, 2012. Canoco reference Manual and user's Guide: Software for ordination, Version 5.0. Microcomputer Power, Ithaca, NY.
TIBCO Software Inc., 2017. Statistica (data analysis software system), version 13. Available from: http://statistica.io

Tsui MTK, Blum JD, Kwon SY, Finlay JC, Balogh SJ, Nollet $\mathrm{YH}, 2012$. Sources and transfers of methylmercury in adjacent river and forest food webs. Environ. Sci. Technol. 46:10957-10964.

Urbanič G, 2014. Hydromorphological degradation impact on benthic invertebrates in large rivers in Slovenia. Hydrobiologia 729:191-207.

Usseglio-Polatera P, Beisel J-N, 2002. Longitudinal changes in macroinvertebrate assemblages in the Meuse River: anthropogenic effects versus natural change. River Res. Appl. 18:197-211.

Vilenica M, Previšić A, Ivković M, Popijač A, Vučković I, Kučinić M, Kerovec M, Gattolliat J-L, Sartori M, Mihaljević Z, 2016. Mayfly (Insecta: Ephemeroptera) assemblages of a regulated perennial Mediterranean river system in the Western Balkans. Biologia 71:1038-1048.

Vilenica M, Mičetić Stanković V, Sartori M, Kučinić M, Mihaljević Z, 2017. Environmental factors affecting mayfly assemblages in tufa-depositing habitats of the Dinaric Karst. Knowl. Manag. Aquat. Ec. 418):1-12.

Vilenica M, Vučković N, Mihaljević Z, 2019. Littoral mayfly assemblages in South-East European man-made lakes. J. Limnol. 78:1853.

Vilenica M, Pozojević I, Vučković N, Mihaljević Z, 2020. How suitable are man-made water bodies as habitats for Odonata? Knowl. Manag. Aquat. Ec. 42:1-10.

Wen L, Rogers K, Ling J, Saintilan N, 2011. The impacts of river regulation and water diversion on the hydrological droughts characteristics in the Lower Murrumbidgee River, Australia. J. Hydrol. 405:382-391.

Williams EB, Chumchal MM, Drenner RW, Kennedy JH, 2017. Seasonality of odonate-mediated methylmercury flux from permanent and semipermanent ponds and potential risk to red-winged blackbirds (Agelaius phoeniceus). Environ. Toxicol. Chem. 36:2833-2837.

Zaninović K, Gajić-Čapka M, Perčec Tadić M, Vučetić M, Milković J, Bajić A, Cindrić K, Cvitan L, Katušin Z, Kaučić D, Likso T, Lončar E, Lončar Ž, Mihajlović D, Pandžić K, Patarčić M, Srnec L, Vučetić V, 2008. [Climate atlas of Croatia 1961-1990, 1971-2000].[in Croatian]. Zagreb, State Hydrometeorological Institute: $200 \mathrm{pp}$.

Zhang Z, Huang J, Gang Y, Hong H, 2004. Occurrence of PAHs, PCBs and organochlorine pesticides in the Tonghui river of Beijing, China. Environ. Pollut. 130:249-261. 